\title{
Sponsorship in Beach Volleyball: effects of event quality, spectator satisfaction and brand experience on brand equity
}

https://doi.org/10.11606/issn.1981-4690.v35i2p207-227

Paula Yumi Yamamoto*
Filipe Quevedo-Silva
Leandro Carlos Mazzei* $^{*}$
*Faculdade de Ciências Aplicadas, Universidade Estadua de Campinas, Limeira, SP, Brazil.

**Universidade Federal do Mato Grosso do Sul, Campo Grande, MS, Brazil.

\begin{abstract}
The aim of this study is to examine the effects of event quality, spectator satisfaction and experience on brand equity of the sponsor in a sport event. In order to carry out this study, 352 spectators that attended the Banco do Brasil (Bank of Brazil) Circuit of Beach Volleyball answered a closed questionnaire. For data analysis, it is used the structural equation modeling. The results indicated that the quality of the event generates satisfaction, which confirms increases the brand equity of the event sponsor. In addition, the spectators' experience with the sponsoring brand also confirms the positive impact on brand equity. The quality of the event, the satisfaction of the spectators with the event and their sponsor's brand experience are elements that, if well managed and explored, contribute positively to sponsors' brand equity. These strategies should be aimed both by sports managers, as a way to attract and retain sponsors, and by sponsors' brand managers, as a way to get return on investment. For this purpose, the sport managers and sponsors should undertake a planning together to offer a high-quality event enabling an environment that provides spectators' satisfaction and a positive experience with the sponsor brand. In theoretical terms, this research brought greater knowledge about the return of investments made by companies on sport sponsorship, and, the use of statistical methods in this study can be replicated, adjusted or even enhanced in future researches that investigate the theme sport events and their sponsors.
\end{abstract}

KeYWORDS: Sport Event; Sponsorship; Experience; Quality; Brand Equity.

\section{Introduction}

Interaction between sport and sponsoring companies is considered a traditional and relevant theme in sport management and marketing area ${ }^{1,2}$. Among the different purposes of sport sponsorship, it is possible to highlight: recognition, recall and the brand equity on the sponsoring companies ${ }^{3-6}$.

There are in the literature, evidence on of several advantages and benefits that a company enjoys when sponsoring sport activities and their events, such as image transfer from the sponsored object to the sponsor ${ }^{7,8}$, recommendation and promotion from people of the sponsor ${ }^{9}$, purchase intent of the sponsor's products or services ${ }^{10,11}$, increase of positive attitude about the sponsoring companies $^{10}$, improvement of Brand Equity ${ }^{12-14}$, among others. However, there is a shortage of studies that investigate the experience that spectators of a sponsored sport events have with the brand of the sponsor.

Focusing on sport events, sport managers face the challenge of attracting and retaining sponsors, who are looking for a return on their investments. One of the ways to meet the needs and persuasion of companies interested in sport event can be the interaction of the spectator with the sponsoring brands, more specifically in the experiences that happen during the sporting event ${ }^{7-10}$.

The interest in investigating the interaction and consequences of experiences that occur among spectators, sport events / organizations and 
sponsoring companies has been gaining increasing prominence over time ${ }^{10}$. In the other hand, the topic of experience in the context of consumer behaviour has been investigated since the 1980s. Holbrook and Hirschman ${ }^{11}$ were pioneers in recognizing the importance of experience in the relation of consumption, focusing their studies on the hedonic, symbolic and aesthetic aspects, besides addressing the experience of consumption as a phenomenon directly related to fantasies, feelings and diversions. Since then, many other definitions of experience had succeeded in many studies that proposing its measurement in the most diverse contexts 20 , including the experience provided by a sporting events ${ }^{15-18}$.

In the last 15 years, Brazil has become an interesting case for researches and studies related to sport events, experience and their sponsorships ${ }^{12}$. Several international mega-events were held in the country, such as Pan American Games in 2007, 2014 FIFA World Cup and Rio 2016 Olympic and Paralympic Games. Numerous companies, including public ones, began to sponsor national sporting events ${ }^{13,14}$. In addition, the mega-events held in the country increased the Brazilian fans expectation on the quality of local and national sporting events. The desire of the spectator is no longer just watching sport performance, but also have the experience of a good entertainment event with quality, as typically offered in major sporting events of global scope ${ }^{15,16}$.

In this context, the aim of this article is to analyze if sporting event quality, spectator satisfaction, experience influence the brand equity of the sponsor of a sporting event. Considering the importance of the volleyball and beach volleyball in the Brazilian context, this study investigates the 2016 Banco do Brasil Beach Volleyball Circuit. It is expected that the event quality associated to a positive event experience and a spectator satisfaction influences sponsor's brand equity. If such relationships are confirmed, the opposite may also be true. A low-quality event can affect negatively the spectator's satisfactions and their brand experience, contributing negatively to sponsor's brand equity.

\section{Literature review}

\section{Sporting event quality and spectator satisfaction}

One aspect that can be considered a "legacy" of the international mega-events held in Brazil was the possibility of part of the Brazilian population to experiment sport events with more quality, close to international standards. Some authors indicate that there are three main aspects that determine the quality of a sporting event: (a) the central product is everything that is related to the performance of the athletes and matches, (b) the peripheral elements, such as the condition of the physical structure of the event (comfort, accessibility, signaling) and interaction with athletes and other spectators are essential, and (c) good experience in the interaction with the event staffs $^{7-8,10,16-17}$. Among the three aspects, the second and the third should be the targets of constant improvement by the event sport managers, whatever the level of the event. The first aspect, performance of the athletes and level of the matches, cannot be controlled by the managers due their unpredictability in the sport context ${ }^{7}$.

On the other hand, globalization influences the perception of the spectators around the world about the quality of sport events. Global events, that offer entertainment allied to quality matches, outbalance the competition and the local preference ${ }^{18,19}$. Thus, Brazilian spectator has new expectations about the satisfaction on sporting events, either by the influence of the mega-events held in the country or by the impact of globalization that exist in our society.

The dimension of satisfaction can be understood as a confirmation of the expectations combined with other aspects perceived during the event $\mathrm{t}^{20}$. Satisfaction is the response to the sport spectacle and to the services provided during the event, which suggests high influence of event quality on the level of satisfaction ${ }^{21}$.

Studies show that the satisfaction in sporting events generates some consequences on spectator behavior ${ }^{22}$. In marketing researches, there are evidence that a satisfied customer causes positively influences in the brand equity of some brand involved with the even ${ }^{23,24}$. In this context, this article also aims to verify the hypothesis that the brand equity of the main sponsor of one event is influenced by the event quality and the spectator satisfaction, considering the hypothesis that satisfaction as consequence of the event quality.

\section{Experience}

The beginning of the experience concept was in the mid of 1980s, when researchers dedicated to understand the importance of consumer experience related to fantasy, feelings and fun ${ }^{11,25}$. Consequently, came to the focus the concept of brand experience. The "brand" experience can be understood as the result of 
experiences that connects the consumer to the brand through stimuli that counteract the traditional forms of marketing promotion ${ }^{26,27}$. Several studies showed the positive relationship between brand experience and brand equity as a possible return for sponsorships $s^{4,28-31}$.

Five dimensions have been proposed by SсHмIтT ${ }^{26,34}$ for experience: (1) Sensorial, relate to the five senses (sight, hearing, touch, taste, smell); (2) Affective, related to the feelings of the consumers and how they are emotionally involved with a given object; (3) Intellectual, related to the challenges, problems solutions or creativity offer by some experience; (4) Behavioral, related to the body and lifestyle; and finally (5) Relational, related to the sense of belonging to a social context. Brakus et al. ${ }^{27}$ empirically tested the dimensions proposed by ScHMITT ${ }^{34}$ through a scale designed to measure consumer's brand opinion based on their experiences. Although other authors have also created a scale for experience ${ }^{4,32-34}$, the measure proposed by BRAKUs et al. ${ }^{27}$ is the most popular in studies about "brand" experience.

In order to provide good experiences to spectators during sporting events, sport managers should carefully look after at some strategies such as building comfortable and assessable facilities, training frontline employees and entertaining the spectators ${ }^{4,2831}$. As a consequence, a good experience may attract sponsors due to the possibility to associate the spectator satisfaction to their brand. Moreover, sports promote the connection between the sponsor and consumer through emotional experiences that are rarely achieved by conventional promotional actions ${ }^{7-10}$. In fact, the sport context is an opportunity for sponsor to explore the five "brand" experience dimensions and to increase their brand equity. In this way, other hypothesis of this study is that brand experience influences the brand equity of the sponsoring company of the sport event. And, do quality event and satisfaction influence the brand experience?

\section{Brand Equity as a return of sport sponsorship}

Brand equity can be defined as the effect of the brand on the mind, ideas and decisions of the consumers ${ }^{35}$. The brand equity can be promoted by two processes: (1) the conscience and image, measured by the intensity of the brand memory (recall); and (2) recognition of the brand, measured by the consumer perceptions of the brand image ${ }^{35}$. When the consciousness and recognition of information are not directly related to consumption, brand image can be confused with a secondary activity, such as the sponsor in sport events. The intensity of this relationship depends on the synergy between sponsor and event sponsored ${ }^{36,37}$.

Sport has become an important context for brand equity strategy ${ }^{38}$. The inherent positive characteristics of the sport, such as the entertainment and the athletes performance, promote the connection between the spectator and the sponsor, provoking a possible loyalty or a good perception on the sponsoring brand ${ }^{39-41}$. Brazilian volleyball and beach volleyball competitions are good examples of sporting events that may improve brand equity. They are internationally recognized by the participation of elite athletes and by promoting high-level matches. These characteristics have made the competitions successful case of sport sponsorship in the past 20 years. The Banco do Brasil, a mixed-economy society, has sponsored volleyball and beach volleyball teams and championships in Brazil since 19914,42.

\section{Methods}

\section{Experimental design}

A structured questionnaire was used to interview spectators who attended to the 2016 Banco do Brasil Beach Volleyball Circuit (Fortaleza/Brazil). The circuit has only one main sponsor, the Banco do Brasil. Banco do Brasil (English: Bank of Brazil) is the largest bank by assets in Brazil and all of Latin America; was founded in 1808 and is the oldest active bank in Brazil $^{51}$. The bank began investing in sports marketing (sponsorship) after a Research International survey in 1989, that showed the bank's customer base ranged in age from 50 to 65 years. The sport was the easiest way out to reach the young. Banco do Brasil has had a long-running association with the Brazilianl volleyball (indoor and beach volleyball national teams $)^{52}$. As already mentioned, the questions and hypotheses measured was the relation with sporting event quality, spectator satisfaction, experience with the brand / event and Banco do Brasil's brand equity. The proposed connections among these variables are represented in the model shown in FIGURE 1. 
FIGURE 1 - Relations among sport event quality, spectator satisfaction, brand equity and brand experience proposed in the research model.

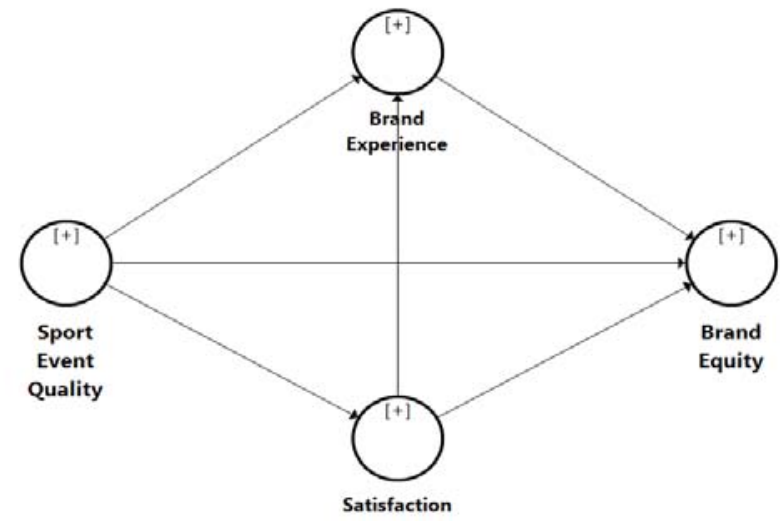

\section{Instruments}

To measure Sport Event Quality, part of the scale of Yoshida and JAmes ${ }^{10}$ was used. This choice was based on the elements inherent to the sport approached by the instrument, such as performance of the players and physical and social environment of the competition. The authors propose a model based on 7 dimensions: game atmosphere; crowd experience; opponent characteristics, player performance; frontline employees; facility access; and seat space.

To measure Satisfaction, MAdRIGaL ${ }^{43}$ scale was used. The choice of this scale was due to the fact that it is frequently used by other studies that aim to analyze satisfaction in the sport. This scale is composed of 3 variables.

(Brand) Experience was measured by the scale of Brakus et al. ${ }^{27}$ adapted by NysveEn et al. ${ }^{44}$. As mentioned in the literature review, the scale of BRAKUS et al. ${ }^{27}$ had been used by several studies and is composed of 12 variables which were tested and validated.

For Brand Equity measurement, part of the scale from Yoo and DonTHu ${ }^{45}$ was adopted. The authors proposed a scale composed by 4 variables, which has been used in other studies involving sport ${ }^{31,46-49}$.

Originally, all scales are from English language, and the Satisfaction and Brand Equity scales already have the validated version in Portuguese and Brazilian culture by Fagundes ${ }^{59}$ and Vargas Neto and $\mathrm{LUCE}^{60}$, respectively. With respect to the other scales, it was necessary to translate them into the Portuguese language and adapt them to the Brazilian culture $^{61}$. In this way, the procedures suggested by BEATON et al. ${ }^{61}$ which consist of 6 stages described below and summarized in FIGURE 2.

From the judges' evaluation for semantic, idiomatic, cultural and conceptual equivalence as part of Stage 4, the suggestions and comments received was evaluated by the authors and a first version of the scales in Portuguese. This first version was conducted with undergraduate students of Physical Education, with the objective of performing the evaluation of the writing and understanding of each items of the questionnaire (also called face validation - Stage 5: Pre-test). Small adaptations were made and the final version (with all dimensions and variables) are presented in APPENDIX A (the Portuguese version). 
FIGURE 2 - Graphical Representation of the stages in the scale's adaptation.

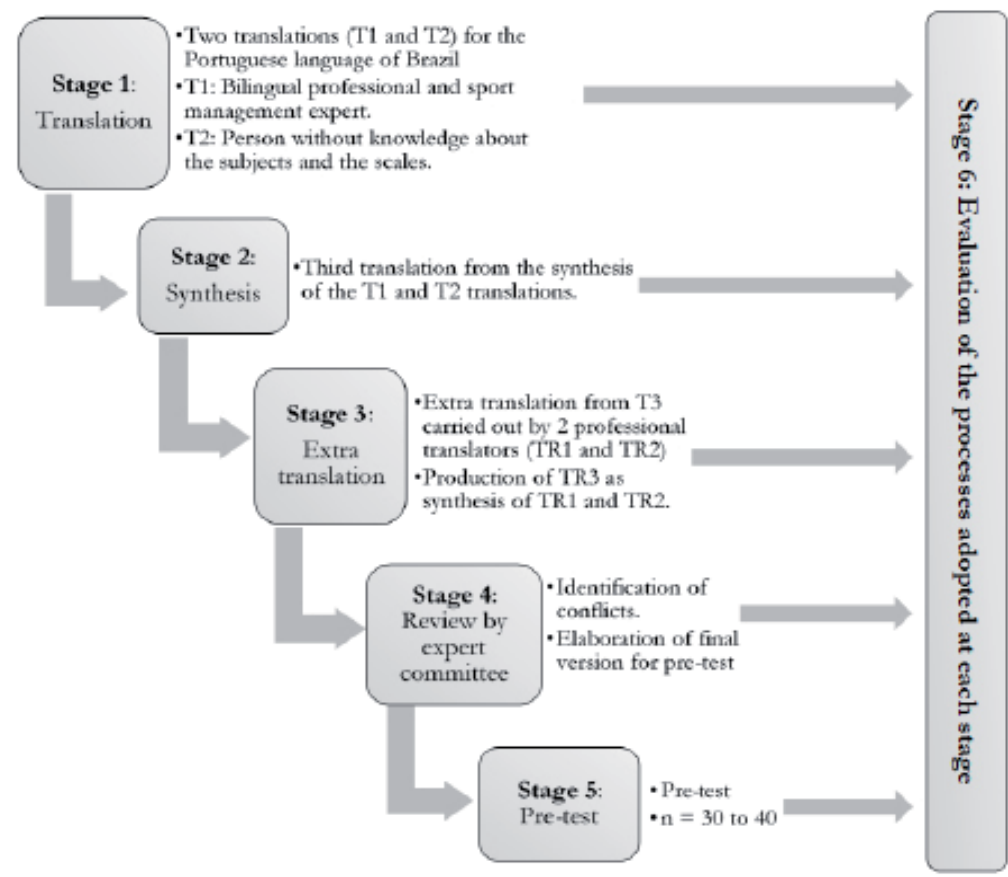

Adapted from: Beaton et al. ${ }^{61}$.

However, the final questionnaire contained 51 variables, presented as statements to be classified on a scale of 5-point Likert. In the Sport Event Quality ${ }^{10}$, the dimension "opponent characteristics" was not included in the final questionnaire given the participation of only Brazilian teams in the championship. Some variables of the dimension "game atmosphere" related to the permanent stadium architecture were also excluded due to the itinerant structure of the arena. TABLE 1 shows the summary of the dimensions, scales and number of variables used.

\section{Data Analysis}

The procedure of Structural Equation Modeling, based on variance (VB-SEM), was chosen for data analysis. All the statistical analyses were performed in the SmartPLS software, version 3.2.4. The VB-SEM is a technique widely used in applied social sciences, mainly because it allows the measurement of latent variables and relationships established between them ${ }^{50,51}$. Through VB-SEM, it is possible to examine how the patterns of relations predicted in theory can be confirmed by empirical data ${ }^{52}$. VB-SEM also maximizes the explained variance of the proposed models by estimating partial least squares adjustments ${ }^{53,54}$. The use of VB-SEM analysis technique is indicated when: a) sample present no normal distribution, b) small sample, c) presence of models in development ${ }^{51,53}$.

In a VB-SEM, first the correlations between dimensions and their variables are calculated, so that correlations between the scales are then made 54 . After checking the coefficients of correlation and the significance of the results, as part of the model evaluation, the explained variance was analyzed through the coefficient of determination $\left(\mathrm{R}^{2}\right)^{55}$. There is no exact rule of acceptance of the $\mathrm{R}^{2}$ value, so its interpretation can be made in order to verify whether the accuracy of the model is strong, medium or weak ${ }^{55}$.

In VB-SEM technique, the arrows define the causal relationships between the components of a model. The component to which the arrow is pointing is a consequence of the one where the arrow originates ${ }^{55}$. The relationship between the scales can be reflexive or formative. In this study, it is assumed that the model is reflexive since the model presents a consequence chaining ${ }^{56}$. The distinction between a reflexive and formative model is important, because it defines how data should be analyzed. Reflective models should be evaluated with respect to their reliability and validity ${ }^{55}$. 
Cronbach's Alpha and Composed Reliability are used to measure the internal consistency. The acceptable limits for both indices are between 0.70 and 0.9555 . Convergent validity through external load values, where the minimum acceptable index is 0.70855 , and Average Variance Extracted (AVE) (greater than 0.50) are used to measure the validity. The discriminant validity through the Fornell-Larcker index was also used. It is a more conservative measure which consists of checking whether the square root of the AVE of a scale is greater than the correlation with another scale ${ }^{55}$.

\section{Participants and Procedures}

Based on the proposed instruments and the data type, it was possible to define the sample size necessary for the viability of this research. There is still no consensus in the literature about the rules to be followed for setting the minimum sample size to the feasibility of a VB-SEM ${ }^{51,55}$. In this study, we choose to use the software $\mathrm{G}^{*}$ Power 3.1 version, as indicated by HaIr et al. ${ }^{51}$. The required parameters for input on software were the "Power of the Test" (Power $=1-\beta$

prob. II $)$ and the "Effect Size" ( $\left.f^{2}\right)$, whose recommended values are 0.15 and 0.80 , respectively ${ }^{55}$. The sample

\section{Results}

\section{Structural Equation Modeling}

In order to determine whether the correlation coefficient is significant it was used bootstrapping technic with $\mathrm{p}<0.05^{54}$. The only relation that is not significant is between Satisfaction and Experience once p-value is greater than 0.05 and Test $t$ is lower than 1.96. The reasons are discussed in next section. Results are shown in TABLE 2.

In order to analyze the proportion of the variance in the Experience that is predictable from the model, it was calculated that the coefficient of determination $\left(\mathrm{R}^{2}\right)$ which is 0.46 . That means that $46.4 \%$ Brand Equity's variance can be explained by Sport Event Quality associated to mediation function of Satisfaction and Experience.

All the results and coefficients obtained from analysis are synthetized in FIGURE 2.

\section{Internal Consistence}

TABLE 3 shows Cronbach's Alpha and Composed size is calculated based on the dependent variable that is related to the greatest number of independent variables $^{54}$. In the proposed model, each dependent variable is related to only one independent variable. The minimum sample size for this study was 55 .

Due to the small sample size estimated, we decided to collect as much data as possible, totaling 352 participants. These spectators attended the matches held during the 2016 Banco do Brasil Beach Volleyball Circuit, in the city of Fortaleza (Brazil). The participants were 181 (52\%) were males and 167 (48\%) females, and 125 (39\%) were between 18 and 24 years old, 73 (23\%) between 25 and 29, 45 (14\%) between 30 and 34, 53 (17\%) between 35 and 44, 17 (5\%) between 45 and 54 years and finally, 8 (2\%) between 55 and 64 years old.

Spectators were approached, randomly, during the intervals of the matches. A team of researchers (who were previously trained on the purpose of the research, how to respond and how to apply the questionnaire) informed the purpose of the study and those who agreed answered the questionnaire. To thank and encourage the participation in the study, we raffled a shirt of the volleyball national team for all the participants and gave them coconut water during the matches.

Reliability as internal consistence measures. All the measures are between the acceptable limits $(\geq 0.70$ and $\leq 0.95)$ and demonstrate that the scales are appropriated to measure what they are proposed to. With these numbers, no dimension or item was excluded from the model.

\section{Validity}

APPENDIX B shows Convergent Validity. As the minimum acceptable limit is 0.70851 , the variable Game Atmosphere 5 (GA5) is the only variable under it (0.6815). However, there is no difference in the Game Atmosphere validity when GA5 is excluded from the model (convergent validity changed from 0.8912 to 0.8868 ). As a consequence, GA5 is kept in the model. AVE index was also used to demonstrate convergent validity. The values should be over 0.5 as a way to guarantee the constructs explain more than $50 \%$ of their indicators variance. Results are shown in TABLE 4. 
TABLE 1 - Dimension and scales used in the questionnaire.

\begin{tabular}{|c|c|c|c|}
\hline Scale & Dimension & Autor & Item Quantity \\
\hline Sport Event Quality & $\begin{array}{c}\text { Frontline employees } \\
\text { Facility access } \\
\text { Seat space } \\
\text { Player Performance } \\
\text { Crowd Experience } \\
\text { Game atmosphere }\end{array}$ & Yoshida and James ${ }^{10}$ & 29 \\
\hline Satisfaction & & & 3 \\
\hline \multirow[t]{2}{*}{ "Brand" Experience } & $\begin{array}{l}\text { Sensory } \\
\text { Affective } \\
\text { Intellectual } \\
\text { Behavioral }\end{array}$ & Brakus et al..$^{27}$ & 12 \\
\hline & Relational & Nysveen et al. ${ }^{44}$ & 3 \\
\hline $\begin{array}{l}\text { Overall Brand } \\
\text { Equity }\end{array}$ & & Yoo and Donthu ${ }^{45}$ & 4 \\
\hline & Total & & 51 \\
\hline
\end{tabular}

TABLE 2 - Relation between the variables brand experience, brand equity, sport event quality and satisfaction.

\begin{tabular}{lcccc}
\hline Relation & Coefficient & Error $(\boldsymbol{\sigma})$ & $\begin{array}{c}\text { Test t } \\
\left(\mid \text { Coef. }^{*} \boldsymbol{\sigma} \mid\right)\end{array}$ & p-value \\
\hline Experience $\rightarrow$ Overall Brand Equity & 0.5484 & 0.0543 & 10.1055 & 0.0000 \\
Sport Event Quality $\rightarrow$ Overall Brand Equity & 0.1135 & 0.0565 & 2.0086 & 0.0447 \\
Sport Event Quality $\rightarrow$ Experience & 0.3994 & 0.0690 & 5.7871 & 0.0000 \\
Sport Event Quality $\rightarrow$ Satisfaction & 0.6576 & 0.0447 & 14.7079 & 0.0000 \\
Satisfaction $\rightarrow$ Overall Brand Equity & 0.1328 & 0.0599 & 2.2159 & 0.0268 \\
Satisfaction $\rightarrow$ Experience & 0.1106 & 0.0625 & 1.7697 & 0.0769 \\
\hline
\end{tabular}


FIGURE 2 - Relation between the variables brand experience, brand equity, sport event quality and satisfaction.

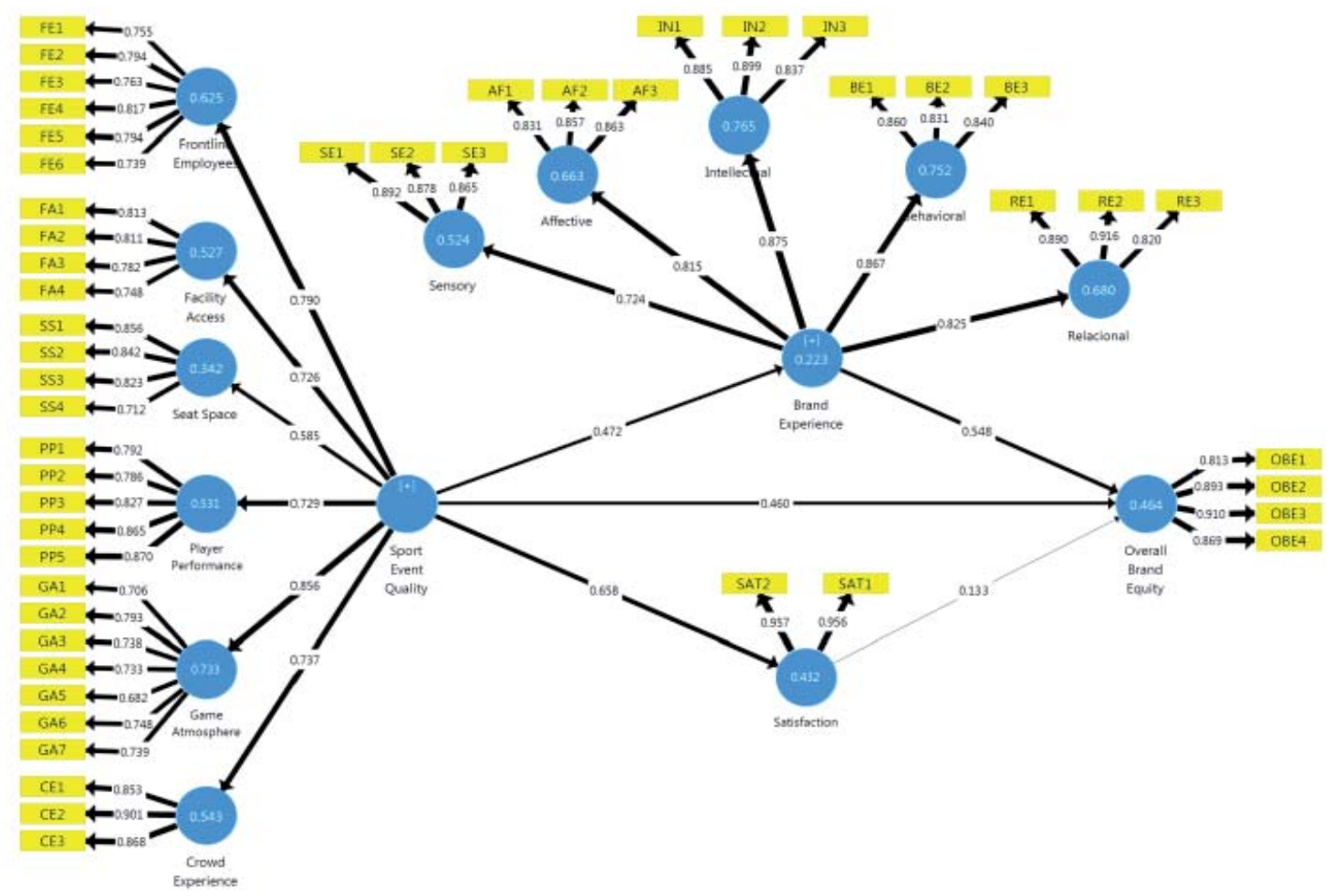

TABLE 3 - Internal consistence of the dimensions of the questionnaires.

\begin{tabular}{lccc}
\hline Dimensions & $\begin{array}{c}\text { Cronbach's } \\
\text { Alpha }\end{array}$ & $\begin{array}{c}\text { Composed } \\
\text { Reliability }\end{array}$ & Number of itens \\
\hline Sport Event Quality & 0.9340 & 0.9403 & 2nd order construct \\
Frontline Employees & 0.8689 & 0.9016 & 6 \\
Facility Access & 0.7980 & 0.8684 & 4 \\
Seat Space & 0.8238 & 0.8837 & 4 \\
Player Performance & 0.8857 & 0.9164 & 5 \\
Game Atmosphere & 0.8574 & 0.8912 & 7 \\
Crowd Experience & 0.8458 & 0.9068 & 3 \\
Satisfaction & 0.9079 & 0.9560 & 2 \\
"Brand" Experience & 0.9283 & 0.9377 & 3 \\
Sensory & 0.8523 & 0.9103 & 3 \\
Affective & 0.8086 & 0.8866 & 3 \\
Intellectual & 0.8452 & 0.9064 & 3 \\
Behavioral & 0.7989 & 0.8813 & 3 \\
Relational & 0.8485 & 0.9081 & 4 \\
Overall Brand Equity & 0.8943 & 0.9268 & 3 \\
\hline
\end{tabular}


TABLE 4 - Average variance extracted (AVE) for each dimension.

\begin{tabular}{lc}
\hline Dimensions & AVE \\
\hline Game Atmosphere & 0.5398 \\
Overall Brand Equity & 0.7603 \\
Intellectual & 0.7636 \\
Behavioral & 0.7123 \\
Seat Comfort & 0.6562 \\
Player Performance & 0.6872 \\
Affective & 0.7228 \\
"Brand" Experience & 0.6766 \\
Frontline Employee & 0.6046 \\
Sport Event Quality & 0.5501 \\
Relational & 0.7675 \\
Satisfaction & 0.9157 \\
Sensory & 0.7718 \\
Facility Access & 0.6228 \\
Crowd Experience & 0.7644 \\
\hline
\end{tabular}

For Discriminant Validity it was used Fornell-Larcker criteria which is based on how much a construct is unique and represents phenomenal that no other construct explains and it is calculated by the AVE root square compared to the correlation between the construct and the others ${ }^{55}$. APPENDIX C shows the results.

\section{Discussion}

The results of this study confirm that the quality of a sporting event influences the brand equity of the sponsoring brand. This result corroborates previous findings that sponsoring companies should pay attention to the process of structuring and planning events even if they are local or national levels. To maximize the return on investments, it should be considered the elements related to the quality of the event. The great attractiveness of a sport competition is the uncertainty of the match outcome. However, this aspect is not capable of planning and control. In this way, sport events managers should focus on other quality elements (peripheral and interaction with event employees).

Peripheral elements can and should be planned and managed in order to increase the quality of the event, especially to be offer an entertainment experience to the spectator. The concept of entertainment relates to cultural, sporting activities, recreation, leisure and sport spectacles that provide fun and exciting experiences, creating pleasant sensations and perceptions in the public ${ }^{57}$.

As shown in FIGURE 2, one of the aspects that presented the greatest influence on the quality of the event was the game atmosphere $\left(\mathrm{R}^{2}=0.733\right)$. This dimension is related to elements that make a friendly and engaging environment. To increase the game atmosphere, it is important to promote the spectator participation and crowd integration to the event. Sport managers and sponsors should plan strategies where the sport event provides reactions from the spectators, such as shouts of encouragement, applause and sighs to make the audience part of the show.

The exposure of a brand in a quality event and the possibility of enhancing its brand equity are some benefits that managers of sport events can present and argue to attract sponsors. However, it is 
important to highlight that quality can be achieved only when responsibilities are shared between the sport event organization and the sponsor company. This symbiotic relationship can promote satisfaction and a good experience with the sponsoring brand in the spectator.

From these factors, it is intuitive to think that, once excellence in quality has been achieved, the positive impact on brand equity will be achieved. However, sponsor managers should consider other factors in the formation of the brand value. In the proposed model the event satisfaction and "brand" experience are also related to the brand equity. From the results, it is possible to confirm that quality is related to the spectator satisfaction. Since satisfaction can be understood as the confirmation of expectations 20 , it can be considered that a satisfied spectator tends to evaluate more positively the sponsor's brand.

The degree of complexity of the proposed model increases when considering, besides quality and satisfaction, spectator's experience with the sponsor's brand during the event. As explored in literature review, the "brand" experience can be understood as any point of contact between the brand and the target audience. Taking the 2016 Banco do Brasil Beach Volleyball Circuit as an example, the first contact with the sponsor ant the spectators can occur even before the beginning of the sport event. The local population of the host city (Fortaleza) was invited by the sponsor to attend the event through billboards, postings on social networks, calls on local radio and television stations. In this way, the interaction between the spectators and the brand is not restricted only to the day of the event.

Pre-event interaction also becomes important in the process of creating expectations. If the expectations are not met, the spectator satisfaction with the event can be compromised. Thus, it is essential to maintain coherence between what is promised and what is delivery as an experience.

Specifically on the experience, it should be highlighted the sensations provoked by the brand, such as visual and other sensory senses ${ }^{27}$. In the event analyzed, the colors of the arena reflected the Banco do Brasil brand (main sponsor), as well as the brand logo was exposure in several elements of event (balls, shirt of the players and referees, nets, etc). The animation was done with mascots and DJ, as well as the distribution of gifts to the spectators ( $t$-shirts, visors and sound accessories). By wearing $\mathrm{t}$-shirts and other accessories with the color and logos of the sponsor, the spectator has the feeling of belonging to the event and consequently the "team" of the sponsor company.

The "brand" experience coefficient (0.548) showed the highest value of brand equity. Corroborating the findings of other authors each point of contact between the sponsor and the spectator serves as a subsidy for the formation of a good spectator experience, and consequently for a greater brand equity of the main sponsor of the event. In addition, sponsor brands should plan strategies and actions for each one of the dimensions of the brand experience during the event, ensuring that they are positive experiences.

It is important to mention that the brand equity and brand experience scale were elaborated to regular organizations (not sports events or sports organizations). But, after the results, it can be concluded that both scaling could be well used in a sport event (in this case a beach volleyball event) and consequently in other studies. Also, it is essential to consider that, in the analyzed object of this study, the sponsoring brand is an important Brazilian bank. In this way, the spectators contact with the sponsoring brand during the games was probably not the first of their lives, which suggests that the value attributed to the brand is probably the result of all the experiences that they have lived previously. In this way, the understanding of the brand equity is multifactorial, but the sponsor in a sport event can contribute to the formation of a positive evaluation of the sport sponsorship companies. Similarly, such investment can be a strategy for the change of the brand equity of companies that have a negative perception by the consumers.

On the other hand, it was not possible to affirm that there is relationship between satisfaction and experience (coefficient of 0.1106 , p-value of 0.0769). The justification of this finding may cause some misunderstanding in the fact that satisfaction and experience act on different objects, in the event and in the sponsor brand, respectively. This result, in fact, is a good indicator to attract sponsors, because it shows that the satisfaction of the spectator is not essential for a good experience with the brand. Even if the team or athlete loses the match, it does not change the experience that the spectator has with the sponsor's brand.

In conclusion, on the practical terms, the results of this study show the needs of sport event managers and sponsoring companies acting together. They should focus on the planning and implementation of aspects related to the quality of the event, satisfaction 
and good experiences for the spectators. The benefits are mutual, for the sport event managers, the agreements with the sponsors can be longer-lasting. For the sponsoring companies, good brand equity can be achieved.

In theoretical terms, this research brought greater knowledge about the return of investments made by companies on sport sponsorship. The good relationships among brand equity and sport event are the resulting from the good spectator satisfaction and experiences form the sponsorship promotion action and from the sport event. Also, the use of statistical methods in this study can be replicated, adjusted or even enhanced in future researches that investigate the theme sport events and their sponsors. On the other hand, given the specificity of this research, it has become complex to compare the results with other studies. One more time, it is essential studies with this theme, mainly in Brazil, to build a consistent theoretical field that involves sport management, sport marketing and sport sponsorship, as defended and verified by others authors ${ }^{70-73}$.

As limitations, it should be mentioned that the value that a spectator and other consumers attribute to a brand is the result of many factors and everyday situations, beyond the sponsor of a sport event. The quality of the event, satisfaction and "brand" experience can intensify or detract the brand equity, that is, just another factor in the opinion of the spectator.

APPENDIX A - Questionnaire items.

\begin{tabular}{|c|c|c|}
\hline Author & Dimension & Qualidade do Evento Esportivo \\
\hline \multirow{17}{*}{ Yoshida and James (18) } & \multirow{7}{*}{ Funcionários do Evento } & $\begin{array}{l}\text { Você acredita que os funcionários neste estádio são } \\
\text { amigáveis. }\end{array}$ \\
\hline & & $\begin{array}{l}\text { A atitude dos funcionários neste estádio demonstra vontade } \\
\text { em ajudar o público presente. }\end{array}$ \\
\hline & & $\begin{array}{l}\text { A atitude dos funcionários neste estádio mostra que eles } \\
\text { entendem suas necessidades. }\end{array}$ \\
\hline & & $\begin{array}{l}\text { Você pode contar com os funcionários do estádio agindo } \\
\text { para atender suas necessidades. }\end{array}$ \\
\hline & & $\begin{array}{l}\text { Os funcionários neste estádio atendem rapidamente suas } \\
\text { necessidades. }\end{array}$ \\
\hline & & $\begin{array}{l}\text { Os funcionários do estádio entendem que você confia no } \\
\text { conhecimento profissional deles. }\end{array}$ \\
\hline & & $\begin{array}{l}\text { Os funcionários do estádio são capazes de responder } \\
\text { rapidamente às suas perguntas. }\end{array}$ \\
\hline & \multirow{4}{*}{ Acesso ao Espaço do evento } & $\begin{array}{l}\text { A sinalização dessa arena te ajuda a saber para onde você } \\
\text { está indo. }\end{array}$ \\
\hline & & $\begin{array}{l}\text { A sinalização dessa arena indica de forma clara onde as } \\
\text { coisas estão localizadas. }\end{array}$ \\
\hline & & A disposiçāo da arena facilita a localização de seu assento. \\
\hline & & A disposição da arena facilita a localização dos sanitários. \\
\hline & \multirow{6}{*}{ Assentos } & Há muito espaço para acomodar os joelhos nos assentos. \\
\hline & & Há muito espaço para acomodar os cotovelos nos assentos. \\
\hline & & A disposição dos assentos proporciona muito espaço. \\
\hline & & Essa arena oferece assentos confortáveis. \\
\hline & & $\begin{array}{l}\text { As vias de circulação são largas o suficiente para lidar com } \\
\text { as multidóes. }\end{array}$ \\
\hline & & $\begin{array}{l}\text { Este estádio oferece espaço suficiente para lidar com as } \\
\text { multidóes. }\end{array}$ \\
\hline
\end{tabular}

Continue 
Continue

APPENDIX A - Questionnaire items.

\begin{tabular}{|c|c|c|}
\hline Author & Dimension & Qualidade do Evento Esportivo \\
\hline \multirow{18}{*}{ Yoshida and James (18) } & \multirow{5}{*}{ Desempenho dos Jogadores } & Jogadores de sua equipe realizam boas jogadas. \\
\hline & & Os jogadores de sua equipe têm habilidades superiores. \\
\hline & & Sua equipe dá $100 \%$ em todo jogo. \\
\hline & & Seu time joga com garra o tempo todo. \\
\hline & & $\begin{array}{l}\text { Os jogadores de sua equipe sempre tentam dar o seu } \\
\text { melhor. }\end{array}$ \\
\hline & \multirow{8}{*}{ Astral dos jogos } & Neste estádio, você acredita que há um bom clima. \\
\hline & & O ambiente deste estádio é o que você quer em um jogo. \\
\hline & & $\begin{array}{l}\text { Você gosta da emoção provocada pelo desempenho dos } \\
\text { jogadores. }\end{array}$ \\
\hline & & $\begin{array}{l}\text { Você curte o entusiasmo associado ao desempenho dos } \\
\text { jogadores. }\end{array}$ \\
\hline & & $\begin{array}{l}\text { Os eventos da(o) (nome da equipe) são um dos melhores } \\
\text { que você já vivenciou. }\end{array}$ \\
\hline & & $\begin{array}{l}\text { O (nome da equipe) vende uma variedade impressionante } \\
\text { de objetos retrô. }\end{array}$ \\
\hline & & $\begin{array}{l}\text { Os itens distribuídos à torcida do (nome da equipe) são de } \\
\text { boa qualidade. }\end{array}$ \\
\hline & & Este estádio está decorado com base em um tema atraente. \\
\hline & \multirow{5}{*}{ Experiência na Torcida } & $\begin{array}{l}\text { Estar rodeado por milhares de fấs em um jogo é uma } \\
\text { grande experiência para você. }\end{array}$ \\
\hline & & $\begin{array}{l}\text { Você está animado por estar com outros fấs que estấo } \\
\text { torcendo, gritando, cantando para o mesmo time que você. }\end{array}$ \\
\hline & & $\begin{array}{l}\text { A energia que você sente da multidão nos jogos te deixa } \\
\text { muito animado. }\end{array}$ \\
\hline & & $\begin{array}{l}\text { Ter a possibilidade de interagir com os jogadores nos jogos } \\
\text { é importante para você. }\end{array}$ \\
\hline & & $\begin{array}{l}\text { O (nome da equipe) entende que o clima é importante para } \\
\text { você. }\end{array}$ \\
\hline \multirow{3}{*}{ Madrigal (53) } & \multirow{3}{*}{ Satisfação } & Eu estou satisfeito com a minha decisão de vir à esses jogos. \\
\hline & & Eu acho que fiz a coisa certa ao decidir vir à esses jogos. \\
\hline & & Eu não estou feliz por ter vindo à esses jogos. \\
\hline \multirow{6}{*}{ Brakus et. al. (35) } & \multirow{4}{*}{ Sensorial } & $\begin{array}{l}\text { Essa marca causa um forte impacto no meu sentido visual } \\
\text { ou nos meus demais sentidos (audição, tato, paladar, } \\
\text { olfato). }\end{array}$ \\
\hline & & $\begin{array}{l}\text { Eu acho essa marca interessante de maneira sensorial (visão, } \\
\text { audição, tato, paladar, olfato). }\end{array}$ \\
\hline & & Essa marca não mexe com os meus sentidos. \\
\hline & & Essa marca induz emoçóes e sentimentos. \\
\hline & \multirow[t]{2}{*}{ Afetivo } & Não tenho fortes emoçóes por essa marca. \\
\hline & & Essa marca é uma marca emocional. \\
\hline
\end{tabular}

Continue 
Continue

APPENDIX A - Questionnaire items.

\begin{tabular}{|c|c|c|}
\hline Author & Dimension & Qualidade do Evento Esportivo \\
\hline \multirow{6}{*}{ Brakus et. al. (35) } & \multirow{3}{*}{ Intelectual } & $\begin{array}{l}\text { Eu me envolvo em ações e comportamentos quando estou } \\
\text { em contato com essa marca. }\end{array}$ \\
\hline & & Essa marca resulta em experiências corporais. \\
\hline & & Essa marca não é voltada para ações. \\
\hline & \multirow{3}{*}{ Comportamental } & $\begin{array}{l}\text { Eu me envolvo em muitos pensamentos quando me deparo } \\
\text { com essa marca. }\end{array}$ \\
\hline & & Essa marca não me faz refletir. \\
\hline & & $\begin{array}{l}\text { Essa marca estimula a minha curiosidade e minha } \\
\text { capacidade de resolver problemas. }\end{array}$ \\
\hline \multirow{3}{*}{$\begin{array}{l}\text { Nysveen, Pedersen and } \\
\text { Skard (54) }\end{array}$} & \multirow{3}{*}{ Relacional } & $\begin{array}{l}\text { Como consumidor da "marca", sinto que sou parte de uma } \\
\text { comunidade. }\end{array}$ \\
\hline & & Sinto que sou parte da família "marca". \\
\hline & & Quando uso "marca" não me sinto abandonado. \\
\hline \multirow{4}{*}{ Yoo and Donthu (13) } & \multirow{4}{*}{ Brand Equity } & $\begin{array}{l}\text { Vale a pena comprar a marca, mesmo quando é igual às } \\
\text { outras. }\end{array}$ \\
\hline & & $\begin{array}{l}\text { Mesmo que outra marca tenha as mesmas características, eu } \\
\text { prefiro comprar a marca. }\end{array}$ \\
\hline & & $\begin{array}{l}\text { Mesmo que haja outra marca tão boa quanto, eu prefiro } \\
\text { comprar a marca. }\end{array}$ \\
\hline & & $\begin{array}{l}\text { Se outra marca não é diferente de nenhuma maneira, parece } \\
\text { mais inteligente comprar a marca. }\end{array}$ \\
\hline
\end{tabular}

Rev Bras Educ Fís Esporte, (São Paulo) 2021 Abr-J un;35(2):207-227• 219 


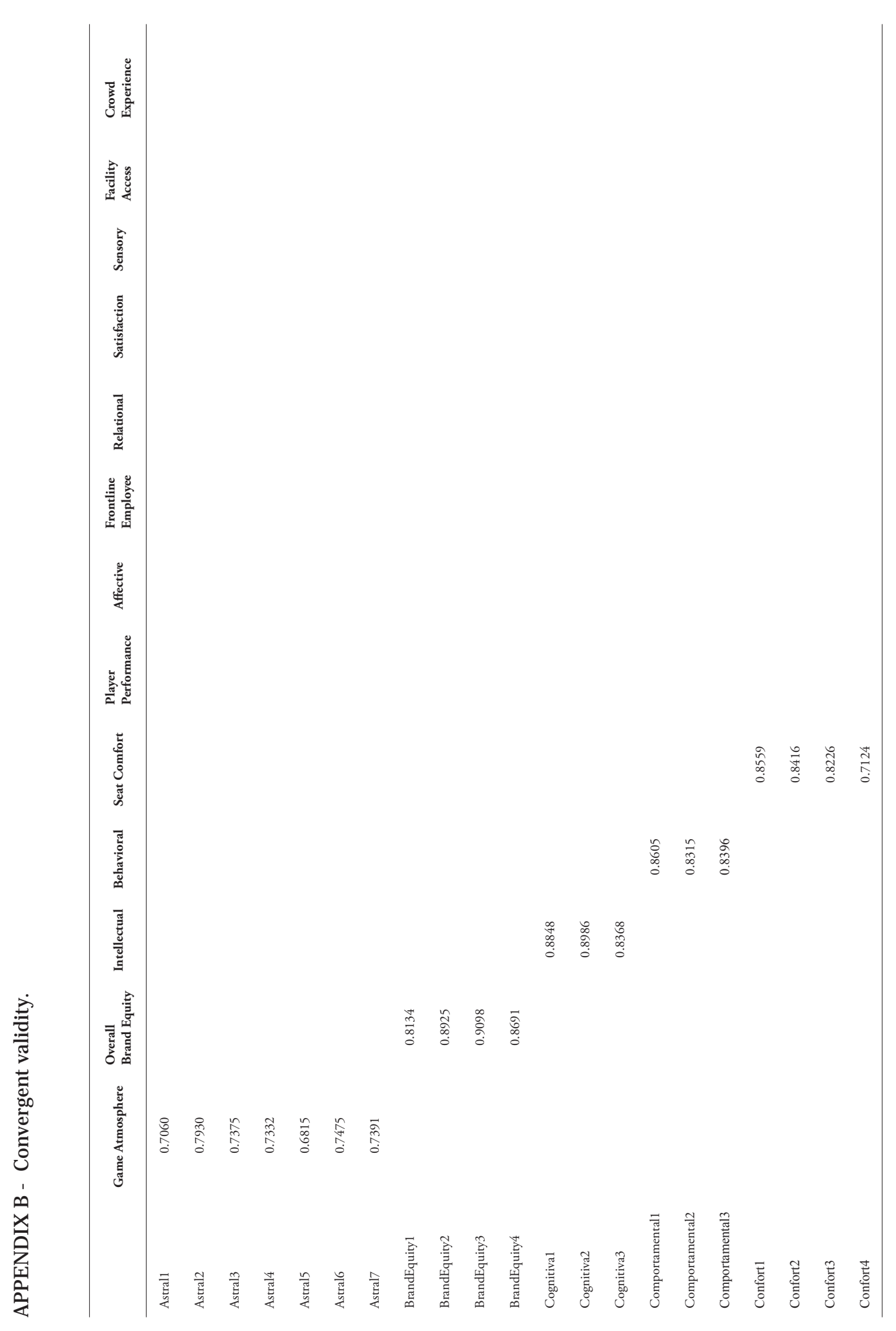




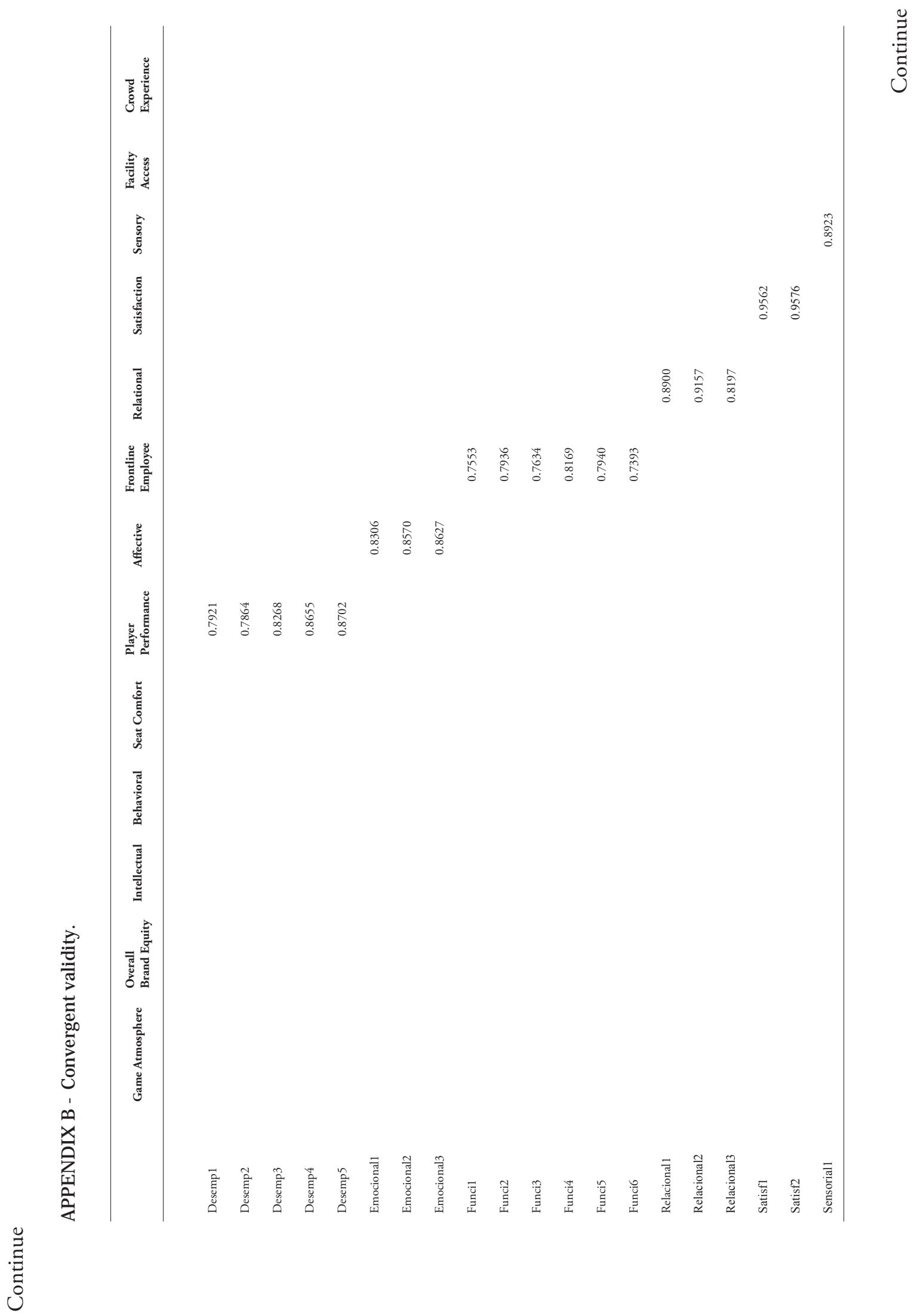

Rev Bras Educ Fís Esporte, (São Paulo) 2021 Abr-J un;35(2):207-227• 221 
Yamamoto PY, et al.

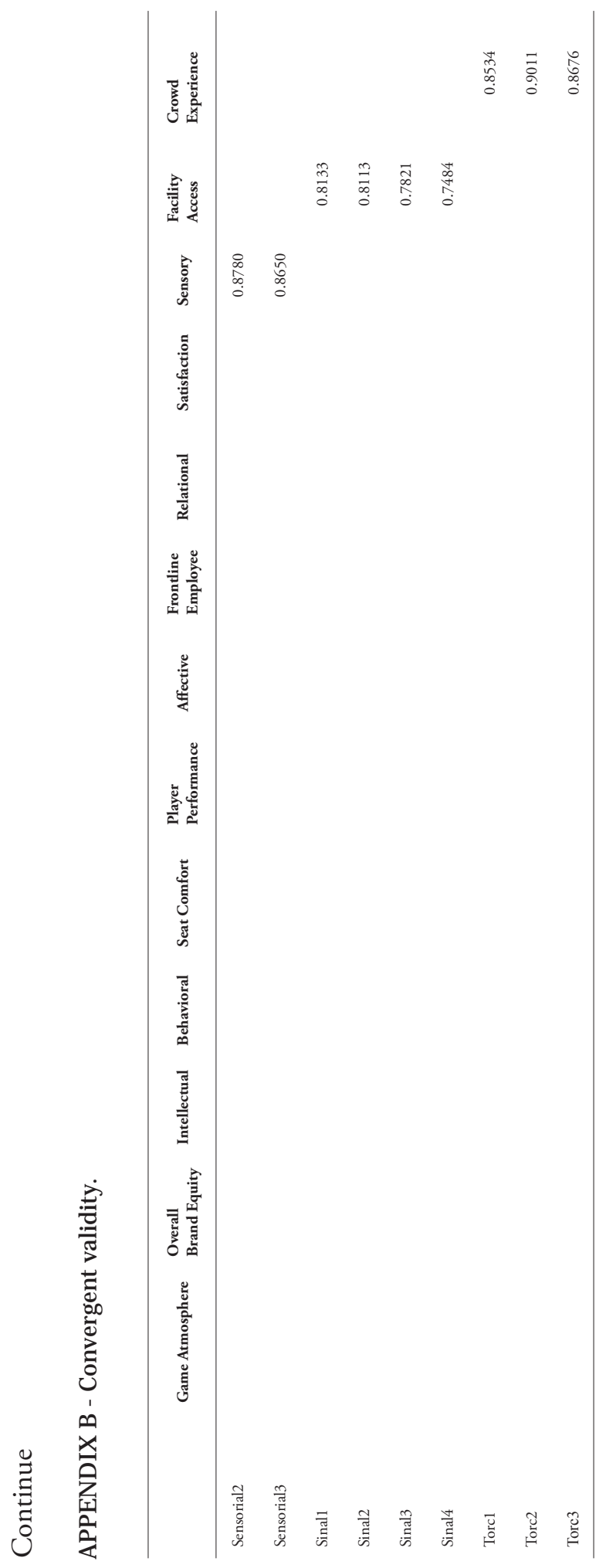

222 • Rev Bras Educ Fís Esporte, (São Paulo) 2021 Abr-J un;35(2):207-227 
Sponsorship in Sport (Beach Volleyball)

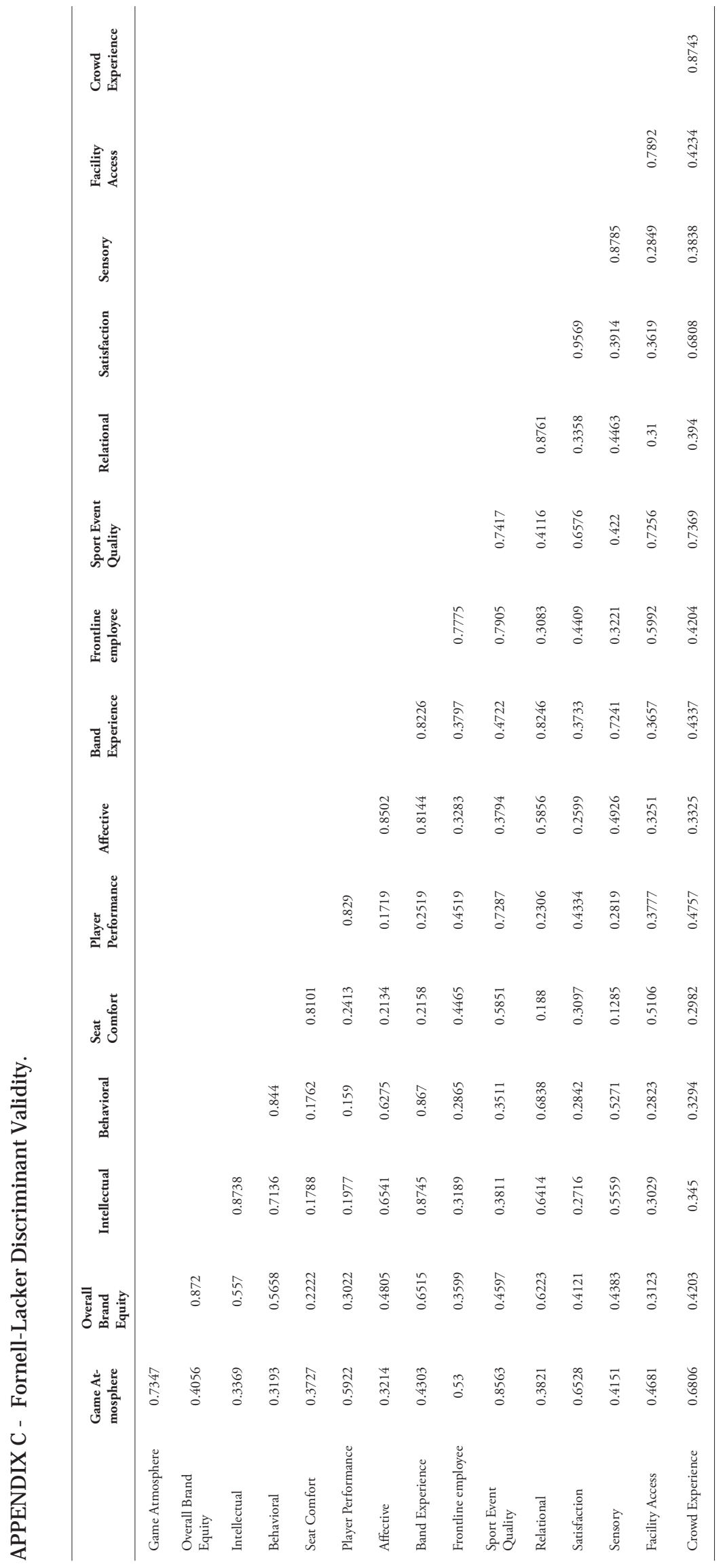

Rev Bras Educ Fís Esporte, (São Paulo) 2021 Abr-J un;35(2):207-227 • 223 


\section{Resumo}

Patrocínio no Voleibol de Praia: efeitos da qualidade do evento, satisfação do espectador e experiência na brand equity

0 objetivo deste estudo foi examinar os efeitos da qualidade do evento, satisfação e experiência do espectador na brand equity do patrocinador de um evento esportivo. Para atingir seu objetivo, 352 espectadores que estiveram presentes no Circuito Banco do Brasil de Voleibol de Praia responderam um questionário padronizados sobre os temas citados. Para a análise de dados, foi usado a modelagem de equações estruturais. Os resultados indicaram que a qualidade do evento gera satisfação, o que confirma o aumento de brand equity para o patrocinador do evento. Além disso, a experiência dos espectadores com a marca do patrocinador também confirma um impacto positivo no brand equity. A qualidade do evento, a satisfação do espectador com o evento e os patrocinadores e as experiencias proporcionadas, são elementos que, se bem geridos e explorados, podem ser caminhos para atrair e reter patrocinadores, e para os gestores, uma forma de justificar os investimentos feitos por empresas em eventos esportivos. Neste propósito, os gestores do esporte e patrocinadores devem planejar em conjunto para oferecer aos espectadores, qualidade, ambiente agradável que proporcionará satisfação e uma experiencias positiva respectivamente e consequentemente uma opinião positiva no brand equity da marca patrocinadora. Em termos teóricos, esta pesquisa proporciona maior conhecimento sobre o retorno dos investimentos feitos pelas empresas através de patrocínios esportivos, além dos métodos estatísticos utilizados neste estudo que podem ser replicados, ajustados ou até mesmo aprimorados em pesquisas futuras que investiguem temas relacionados com os eventos esportivos e seus patrocinadores.

Palavras-chave: Evento Esportivo; Patrocínio; Experiência; Qualidade; Brand Equity.

\section{References}

1. Pitts BG, Stotlar DK. Fundamentals of sport marketing. Morgantown: Fitness Information Technology; 2013.

2. Masteralexis LP, Barr C, Hums M. Principles and Practice of Sport Management. 4th ed. Sudbury: Jones \& Bartlett Learning; 2011.

3. Alexander N. Defining brand values through sponsorship. Runyan RC, editor. Int J Retail Distrib Manag. 2009;37(4):346-57.

4. Fransen ML, Rompay TJL van, Muntinga DG. Increasing sponsorship effectiveness through brand experience. Int J Sport Mark Spons. 2013;14(2):37-50.

5. Hansen F, Martensen A, Riis Christensen S. Modelling emotional and attitudinal responses as drivers of sponsorship value. Int J Sport Mark Spons. 2005;7(1):69-74.

6. Grimes E, Meenaghan T. Focusing commercial sponsorship on the internal corporate audience. Int J Advert. 1998;17(1):51-74.

7. Smith G. Brand Image Transfer Through Sponsorship: A Consumer Learning Perspective. J Mark Manag. 2004;20(34):457-74.

8. Gwinner K. A model of image creation and image transfer in event sponsorship. Int Mark Rev. 1997;14(3):145-58.

9. Tsiotsou R, Alexandris K. Delineating the outcomes of sponsorship. Int J Retail Distrib Manag. 2009;37(4):358-69.

10. Biscaia R, Correia A, Rosado AF, Ross SD, Maroco J. Sport sponsorship: The relationship between team loyalty, sponsorship awareness, attitude toward the sponsor, and purchase intentions. J Sport Manag. 2013;27(4):288-302.

11. Chavanat N, Martinent G, Ferrand A. Sponsor and Sponsees Interactions: Effects on Consumers' Perceptions of Brand Image, Brand Attachment and Purchasing Intention. J Sport Manag. 2009;644-70.

12. Bibby DN. Brand image, equity, and sports sponsorship. Adv Cult Tour Hosp Res. 2009;3(1):21-99.

13. Yoo B, Donthu N. Developing and validating a multidimensional consumer-based brand equity scale. J Bus Res. 2001;52(1):1-14.

14. Henseler J, Wilson B, Westberg K. Managers' Perceptions of the Impact of Sport Sponsorship on Brand Equity : Which Aspects of the Sponsorship Matter Most? Sport Mark Q. 2011;20(1):7-21.

15. Clemes MD, Brush GJ, Collins MJ. Analysing the professional sport experience: A hierarchical approach. Sport Manag 
Rev. 2011;14(4):370-88.

16. Ko YJ, Zhang J, Cattani K, Pastore D. Assessment of event quality in major spectator sports. Manag Serv Qual. 2011;21:304-22.

17. Theodorakis ND, Kambitsis C, Laios A, Koustelios A. Relationship between measures of service quality and satisfaction of spectators in professional sports. Manag Serv Qual. 2001;11(6):431-8.

18. Yoshida M, James JD. Service quality at sporting events: Is aesthetic quality a missing dimension? Sport Manag Rev. 2011;14(1):13-24.

19. Holbrook MB, Hirschman EC. The experiential aspects of consumption: consumer fantasies, feelings, and fun. J Consumer Res. 1982;9:132.

20. Garg R, Rahman Z, Qureshi MN. Measuring customer experience in banks: scale development and validation. J Model Manag. 2014;9(1):87-117.

21. Mazzei LC, Oliveira NS, Rocco Jr AJ, Bastos FC. Uma análise da produção acadêmica brasileira em Marketing Esportivo enquanto área multidisciplinar. REMark Rev Bras Mark. 2013;12(4):183-200.

22. Mazzei LC, Yamamoto PY, Cury RL, Bastos FC. Diagnóstico e possíveis determinantes dos patrocínios no esporte olímpico brasileiro. Pulsar. 2014;6(4):1-16.

23. Vlastuin J, Almeida BS, Marchi Jr W. O marketing esportivo na gestão do voleibol brasileiro: fragmentos teóricos referentes ao processo de espetacularização da modalidade. Rev Bras Ciências do Esporte. 2008;29(3):9-24.

24. Marques RFR, Gutierrez GL, Montagner PC. Novas configuraçôes socioeconomicas do esporte na era da globalização. J Phys Educ. 2009;20(4):637-48.

25. Rocco AJ, Mazzei LC. Os novos estádios e arenas do futebol brasileiro, o padrão Fifa e o consumidor do esporte: o legado da Copa do Mundo 2014 e suas aproximaçóes com o entretenimento. In: Araújo AC, editor. Copa do Mundo 2014: debates sobre mídia e cultura. Natal: EDUFRN; 2015. p. 181-210.

26. Greenwell TC, Fink JS, Pastore DL. Assessing the influence of the physical sports facility on customer satisfaction within the context of the service experience. Sport Manag Rev. 2002;5(2):129-48.

27. Grieve FG, Zapalac RK, Wann DJ, Visek AJ, Partridge JA, Lanter JR. The importance of team identification in perceptions of trust of fellow and rival sport fans. In: Earnheardt AC, Haridakis PM, Hugenberg BS, editors. Sports fans, identity, and socialization exploring the fandemonium. Lanham: Lexington Books; 2009. p. 79-90.

28. Norris JI, Wann DL, Zapalac RK. Sport fan maximizing: following the best team or being the best fan? J Consum Mark J Consum Mark. 2015;32(3):157-66.

29. Van Leeuwen L, Quick S, Daniel K. The sport spectator satisfaction model: a conceptual framework for understanding the satisfaction of spectators. Sport Manag Rev. 2002;5(2):99-128.

30. Yoshida M, James JD. Customer satisfaction with game and service experiences: antecedents and consequences. Recreation. 2010;24(3):338-61.

31. Theodorakis ND, Alexandris K, Tsigilis N, Karvounis S. Predicting spectators' behavioural intentions in professional football: The role of satisfaction and service quality. Sport Manag Rev. 2013;16(1):85-96.

32. Torres A, Tribó JA. Customer satisfaction and brand equity. J Bus Res. 2011;64(10):1089-96.

33. Pappu R, Quester P. Does customer satisfaction lead to improved brand equity? An empirical examination of two categories of retail brands. J Prod Brand Manag. 2006;15(1):4-14.

34. Schmitt BH. Experiential Marketing. J Mark Manag. 1999;15(1-3):53-67.

35. Brakus JJ, Schmitt BH, Zarantonello L. Brand experience: what is it? How is it measured? Does it affect loyalty? J Mark. 2009;73(3):52-68.

36. Lin YH. Innovative brand experience's influence on brand equity and brand satisfaction. J Bus Res. 2015 Nov;68(11):6.

37. Dolbec P-YP-Y, Chebat J-CJ-C. The impact of a flagship vs. a brand store on brand attitude, brand attachment and brand equity. J Retail. 2013;89(4):460-6.

38. Kumar RS, Dash S, Purwar PC. The nature and antecedents of brand equity and its dimensions. Mark Intell Plan. 2013;31(2):141-59.

39. Schmitt BH, Zarantonello L. Consumer experience and experiential marketing: a critical review. Rev Mark Res. 2013;10(2013):25-61.

40. Lee TH, Chang YS. The influence of experiential marketing and activity involvement on the loyalty intentions of wine tourists in Taiwan. Leis Stud. 2012 Jan;31(1):103-21.

41. Nadiri H, Gunay GN. An empirical study to diagnose the outcomes of customers' experiences in trendy coffee shops. J Bus Econ Manag. 2013;14(1):22-53. 
42. Tao S-P. Experiential marketing and marketing experience: an empirical study of the influence of summer boot camp on military propensity. Mil Psychol. 2014;26(5-6):422-33.

43. Keller KL. Conceptualizing, measuring, and managing customer-based brand equity. J Mark. 1993;57(1):1-22.

44. Morgan MJ, Summers J. Marketing esportivo. São Paulo: Thomson Learning; 2008.

45. Navarro A, Sicilia M, Delgado-Ballester E. Integrated marketing communications: Effects of advertising-sponsorship strategic consistenc. EuroMed J Bus. 2009;4(3):223-36.

46. Cornwell TB, Kwak DH. Sponsorship-Linked Marketing: Introduction to Topics. J Sport Manag. 2015;29(2):133-6.

47. Roy DP, Cornwell TB. Brand equity's influence on responses to event sponsorships. J Prod Brand Manag. 2003;12(6):377-93.

48. Donlan LK. The Role of Brand Knowledge in Determining Sponsorship Effectiveness. J Promot Manag. 2013;19(2):24164.

49. Chieng FYL, Lee GC. Customer-Based Brand Equity : a Literature Review. J Arts Sci Commer. 2011;2(1):33-42.

50. Maroni FC, Mendes DR, Bastos FC. Gestão do voleibol no Brasil: o caso das equipes participantes da Superliga 20072008. Rev Bras Educ Fís Esporte. 2010;24(2):239-48.

51. Banco do Brasil on the Forbes World's Best Employers List [Internet]. 2018 [cited 2019 Mar 14]. Available from: https://www.forbes.com/companies/banco-do-brasil/\#7dd696ce51c3

52. Terra T. Banco do Brasil e Caixa conquistam clientes com marketing esportivo [Internet]. 2019 [cited 2019 Mar 14]. Available from: https://exame.abril.com.br/marketing/banco-brasil-caixa-conquistam-clientes-marketingesportivo-563154/

53. Madrigal R. Cognitive and affective determinants of fan satisfaction with sporting attendance. J Leisure Research. 1995;27(3):205-227.

54. Nysveen H, Pedersen PE, Skard S. Brand experiences in service organizations: Exploring the individual effects of brand experience dimensions. J Brand Manag. 2013;20(5):404-23.

55. Washburn JH, Plank RE. Measuring brand equity: an evaluation of customer-based brand equity scale. J Marketing Theory and Practice. 2002;10(1): 46-62.

56. Vargas Neto A. Mensuração de brand equity baseada no consumidor : avaliação de escala multidimensional. Universidade Federal do Rio Grande do Sul; 2003.

57. Fernández E, Delgado M. Marcas de experiencia: marcando la diferencia. Estud Gerenciales. 2011;27(121):59-77.

58. Kang S, Hur W-M. Investigating the antecedents of green brand equity: a sustainable development perspective. Corp Soc Responsib Environ Manag. 2012;19(5):306-16.

59. Fagundes AFA. Um modelo dos fatores que influenciam a satisfação dos torcedores na ida aos estádios de futebol no brasil e sua intenção de retorno. Universidade Federal de Minas Gerais; 2013.

60. Vargas Neto A, Luce FB. Mensuração de brand equity baseado no consumidor: avaliação de escala multidimensional. In: II EMA - Encontro de Marketing da ANPAD. Rio de Janeiro; 2006. p. 1-16.

61. Beaton DE, Bombardier C, Guillemin F, Ferraz MB. Guidelines for the process of cross-cultural adaptation of selfreport measures. Spine. 2000;25(24):3186-91.

62. Monecke A, Leisch F. semPLS : Structural equation modeling using partial least squares. J Stat Softw. 2012;48(3).

63. Hair JF, Hult TM, Ringle CM, Sarstedt M. A primer on partial least squares structural equation modeling (PLS-SEM). Los Angeles: Sage Publications Inc; 2014.

64. Fan X, Thompson B, Wang L. Structural equation modeling: a multidisciplinary effects of sample size, estimation methods, and model specification on structural equation modeling fit indexes. Struct Equ Model A Multidiscip J. 1999;6(1):56-83.

65. Hair JF, Sarstedt M, Ringle CM, Mena JA. An assessment of the use of partial least squares structural equation modeling in marketing research. J Acad Mark Sci. 2012;40(3):414-33.

66. Ringle CM, Da Silva D, Bido DDS. Modelagem de equaçóes estruturais com utilização do SmartPLS. Rev Bras Mark. 2014;13(2):56-73.

67. Hair JF, Sarstedt M, Hopkins L, Kuppelwieser VG. Partial least squares structural equation modeling (PLS-SEM). Eur Bus Rev. 2014;26(2):106-21.

68. Rossiter JR. The C-OA-SE procedure for scale development in marketing. Int J Res Mark. 2002;19(4):305-35.

69. Kaser K, Oelkers DB. Sports and entretainment marketing. 4th ed. Boston: South-Western, Cengage Learning; 2014.

70. Rocha CM, Bastos FC. Gestão do esporte: definindo a área. Rev Bras Educ Fís Esporte. 2011;25(nesp):91-103.

71. Mazzei LC, Rocco Júnior AJ. Um ensaio sobre a Gestão do Esporte: um momento para a sua afirmação no Brasil. Rev 
Gestão Neg Esporte. 2017;2(1):96-109.

72. Mattar FN, Mattar MF. Gestão de Negócios Esportivos. Rio de Janeiro: Elsevier; 2013.

73. Pires GMV da S, Sarmento JPS de RL. Conceito de Gestão do Desporto. Novos desafios, diferentes soluçóes. Rev Port Ciênc Desporto. 2001;1(1):88-103.

\begin{tabular}{r|l} 
ADDRESS & \\
Leandro Carlos Mazzei & \\
R. Pedro Zaccaria, 1300 & Submited: 2019/03/14 \\
350 - Limeira - SP - Brazil & Revised: 2019/03/14 \\
leandromazzei@gmail.com & Accepted: 2021/05/24 \\
o.mazzei@fca.unicamp.br &
\end{tabular}

leandro.mazzei@fca.unicamp.br 